\title{
Advanced Empirical Research Based on Structural Equation Modeling (SEM) Regarding the Impact of Tax Revenue on GDP Dynamics at EU-28 Level
}

\author{
Cristi Spulbar ${ }^{*} \mathbb{D}$, Mohammad Ehsanifar**iD, Ramona Birau***iD, \\ Arezoo Babaie ${ }^{\S}$, Daniel Iulius Doagă
}

\begin{abstract}
The main objective of this empirical study is to investigate the impact of tax revenue on GDP dynamics at EU-28 level based on structural equation modeling (SEM). We applied structural equation modeling (SEM) which represents a multivariate statistical analysis technique used especially for analyzing structural relationships between measured variables and latent structures. Selected taxes are the following: environmental taxes, indirect taxes, social contributions, taxes on capital, taxes on labor, taxes on property, and direct taxes. The sample period includes a long-time horizon during 2005-2017 for each member states of EU-28. Our empirical findings revealed the level of taxation exhibits an increased influence on GDP dynamics in case of EU-28 member states.
\end{abstract}

Keywords: taxation; structural equation modeling (SEM); economic growth; fiscal policy; GDP; regression analysis.

JEL classification: C3; E62; O47; O52.

\section{INTRODUCTION}

The current globalized society is characterized by the need for redistribution processes due to the fulfillment of the basic functions of the state. At the same time, government spending as the main instrument of economic policy is conditioned by the need to finance it, where tax revenues are usually the most significant part of state budget revenues. In order to

\footnotetext{
Faculty of Economics and Business Administration, University of Craiova, Romania; e-mail: cristi_spulbar@yahoo.com (corresponding author).

** Department of Industrial Engineering, Arak Branch, Islamic Azad University, Arak, Iran; e-mail: M-Ehsanifar@iau-arak.ac.ir.

Faculty of Education Science, Law and Public Administration, Constantin Brancusi University of Targu Jiu, Romania; e-mail: ramona.f.birau@gmail.com.

${ }^{\S}$ Department of Industrial Engineering, Arak Branch, Islamic Azad University, Arak, Iran; e-mail: arezoobabai69@gmail.com. Faculty of Economics and Business Administration, University of Craiova, Romania; e-mail: daniel.doaga1970@gmail.com.
} 
have a representative overview, it is necessary to investigate the correlation between taxes (fiscal burden) and economic growth (as a basic objective of economic policy makers) (Macek, 2015). Contemporary fiscal policies pursue the diversity of policy objectives. Thus, taxation aims not only to raise the necessary funds for government spending, but also to contribute to the redistribution of income, economic stability, efficient allocation of resources, but at the same time should support economic growth. The purpose of a properly designed tax system is to achieve the objectives of the desired fiscal policy in the most efficient way, namely by limiting undesirable distortions, minimizing the costs of tax collection and promoting economic growth. The efficiency of taxation and especially the tax structure play an important role in achieving economic growth and fiscal consolidation (Stoilova, 2016). Stiglitz (2010) considers that the most significant aspect regarding public policy approach is represented by the structure and level of taxes. Taxation is a specific lever of fiscal policy but very important for the development of national economies. The goal of developed countries in terms of fiscal policy is to achieve economic stability.

Haas et al. (2020) considers that even from the starting point, the European integration designing plan was characterized by uncertainties regarding the real possibility of fiscal and economic policy coordination. It was empirically established in the literature that fiscal policy has an impact on economic growth. The European Commission (2019) highlighted that macroeconomic imbalances implicitly leads to the vulnerability of the European Union members based on negative macroeconomic shocks and increased possibility of economic recessions. Fiscal policy is the means by which the government adjusts its expenditures and revenues in order to influence the economy as a whole. By adjusting its level of tax expenditures, the government can affect the economic growth either by increasing or decreasing short-term economic activity. Nayak et al. (2021) consider that government expenditure is strongly interconnected with concept of economic growth and represents the driving force of each country. Moreover, Spulbar et al. (2020b) highlighted the fact that financial liberalization implies the possibility of attracting significant investment opportunities based on the positive effects of economic growth.

The main objectives of fiscal policy aim to achieve and maintain full employment or at least as high as possible in terms of labor, achieving a high rate of economic growth and maintaining stable prices and wages. But, fiscal policy is also used to reduce inflation, to increase aggregate demand, but also for other macroeconomic issues. The aggregate demand has a dimension that is under the strong influence of prices. Moreover, aggregate demand is also known as global demand. It comprises all the solvent requests for goods and services that have been produced at the level of a certain economy, in the context of a certain predetermined time interval and at a general average threshold related to their prices. Governments use fiscal policy to influence the level of aggregate demand in the economy so that certain economic goals can be achieved, such as: price stability, reducing unemployment, economic growth.

In case of developing countries, determining whether the tax contributions meet the established vision of citizens is often a complicated situation of greater doubt regarding the effective representation of political systems. Moreover, different forms of tax reduction behavior will determine different social and political implications. However, in terms of direct economic impact, it should be noted that in this context, the importance of tax evasion (or any other form of tax reduction behavior) for developing countries it does not consist in the form it takes, but rather in its effects. The key is to take into account existing fiscal structures in terms of their impact on socio-economic development. This takes place through both revenue 
and non-revenue channels, leading to different outcomes in the following directions: growth, poverty, social inequality and political representation. Tanzi and Zee (2000) suggested that developing countries represent a special case in the context of their emerging markets so the tax policy has a priority to collect sufficient revenue in order to finance the main expenditures but without leading to unreasonable public sector borrowing.

This research paper is organized as follows: the first section includes the introduction, while Section 2 discusses the literature review. Moreover, Section 3 examined key issues regarding applied methodology based on structural equation modeling (SEM) and Section 4 deals with empirical analysis. Empirical results and discussion are explained in Section 5, while conclusions, limitations and future research are explained in the Section 6.

\section{LITERATURE REVIEW}

Trivedi et al. (2021) argued that the global financial crises (GFC) of 2007-2009 significantly affected the real sector of the economy so the economic growth decreased, while unemployment rate increased. Since the global financial crisis, EU-28 member states have faced the difficult challenge of consolidating their budgets, while promoting economic growth. The average budget aggregates in EU-28 member states have clearly expressed their cyclical dynamics in the period 1996-2014. EU member states, and in particular those in the EU-15, have traditionally highlighted a strong social protection, which means higher amounts allocated to government spending and the respective tax burden. On the other hand, EU-15 countries, or so-called "old" countries, include the following: Belgium, Denmark, Germany, Ireland, Greece, France, Italy, Luxembourg, the Netherlands, Austria, Portugal, Spain, Finland, Sweden, while the United Kingdom have completed the BREXIT process. It is clear that proxies for economic development such as GDP per capita, industrial sector and civil liberties have a positive impact on tax revenues (Castro and Camarillo, 2014). Significantly lower public spending and fiscal burden are reported by the new member states (Eastern and Southern European countries), mainly as a result of the liberal economic reforms of the democratic transition (Stoilova, 2016). Despite the fact that there is no doubt that fiscal policy can influence economic choices, it is by no means obvious, on an ex ante basis, that the reduction of tax rates will eventually lead to a wider and more efficient economy (Gale and Samwick, 2014). Moreover, Spulbar et al. (2020a) suggested that integration and economic convergence represent fundamental elements in the structure of the European Union.

In the literature, Judd (1985) was one of the first researchers to analyze the productivity of government spending and its impact on economic growth in close connection with its financing based on different types of taxes. When assessing the impact of fiscal variables on economic growth, it is necessary to start from the fact that taxation influences economic growth only through its impact on individual growth variables (Kotlan et al., 2011). Growth theories can be considered as key elements in this assessment and it is therefore necessary to consider, at least in the case of short-term time horizon, their influence and to describe the impact of taxation channels and leverage on economic growth. Babatunde et al. (2017) have conducted a complex research study in order to investigate the relationship between taxation and economic growth in Africa for the period 2004 - 2013. The pre-estimation test included descriptive statistics and the unit root test, which revealed that the variables GDP and taxes were normal and stationary. This empirical study confirms the significant positive influence of tax revenues on gross domestic product. This study is in line with the position of Ibn 
Khaldun's theory of taxation which postulates that a lower tax rate has a positive impact on production and economic performance. It seems that the selected African economies have generated sufficient domestic tax revenues in order to guarantee economic performance. It is also reported that foreign direct investment has a positive influence on economic growth.

The growth theory of the 1950s and 1960s, formulated by Solow (1956) and Swan (1956), was based on a production function that had capital and labor (with labor measured in man-hours) as production inputs. Constant returns to scale were expected, as well as a decrease in the marginal productivity of both inputs. The increase took place in the model through the accumulation of capital, but without exogenous changes, there had to be a limit to this process. In order to obtain this effect, we can consider an economy with a fixed population in which each person works a fixed number of hours and capital depreciates completely when it is used (Myles, 2000). The theory of tax benefits developed by Cooper (1994) suggests that taxes should be imposed on individuals based on the benefit conferred on them. In fact, the more benefits a person derives from state activities, the more he or she should pay to the government, thus expecting a "quid pro quo". However, it is impossible to implement this theory precisely because of the difficulty of determining the amount of government benefits, including diffuse benefits, such as the military protection received by each resident and non-resident taxpayer.

Gashi et al. (2018) analyzed the effect of the tax structure on the economic growth of the Kosovo region in the period 2007-2015. The study aimed to assess the impact of certain types of taxes on economic growth. The methodology is based on a comparative analysis of selected data using primary and secondary sources. The econometric model includes several independent variables (tax types / categories) and the GDP dependent variable. Based on the data obtained through the log-log model, the results show the impact of excise duties such as $\mathrm{Pt}$, It, VAT, Wt, Ibt, Tdr .., Ct on GDP. The results reveal that most taxes have a positive impact on GDP growth, while not all taxes have the same impact on economic growth. In the econometric analysis, the coefficient $\mathrm{R} 2=0.999$ reflects the high degree of determination with a prediction accuracy of approximately $99.9 \%$.

Hayat et al. (2021) suggested that economic growth represents the capacity of a certain country to increase its level of output. Easterly and Rebelo (1993) consider that a large majority of the growth models forecast the fact that taxes on investment and income exhibit destructive impact on growth. Lee and Gordon (2005) investigated the nexus between tax system and economic growth for the sample period 1970-1997 and concluded that increases in corporate tax rates causes a decrease in future growth rates. Lapatinas et al. (2019) argued that fiscal policy implies a direct effect on economic growth, but also exhibits an indirect effect on economic development. Moreover, Auerbach and Smetters (2017) examined relevant aspects regarding tax policy, including essential elements on how individual income tax influence long-term economic growth.

The tax structure based on selective taxation, such as consumption, personal income tax and property tax, further support economic growth (Stoilova, 2016). Reducing the consumption taxation rate on commodities and increasing the taxation rate on luxury goods have a positive effect on GDP growth (Asllani and Statovci, 2018). Corporate income taxes have the greatest impact on GDP per capita, while real estate taxes and in particular the tax on the right of reuse on real estate have a higher positive effect on growth, as well as consumption taxes and personal income taxes (Arnold, 2008). A high level of corporate taxes discourages potential investors from investing. Direct taxes have a negative impact on the 
GDP per capita growth rate and a strong negative impact on the accumulation of physical capital (Romero and Strauch, 2008). Khumbuzile and Hlalefang (2018) suggested that most previous studies also identify a negative and strong relationship between taxes and growth. The government should pursue effective macroeconomic policies, along with significant improvements in the structure and functioning of governance systems in order to stabilize economic growth, such as changes in fiscal policy. According to the empirical results, it is considered that it would be vital to reduce indirect taxes and increase direct taxes for raising the economic growth.

Gius and Frese (2002) find that lower personal income taxes increase the number of companies, but corporate taxes do not have a significant impact. Goss and Phillips (1994) consider that personal income taxes reduce the employment increase, but income taxes do not have this effect. Also, Shuai and Chmura (2013) find that higher corporate taxes reduce employment growth. Chigbu et al. (2012) conducted an empirical study on Nigeria for the sample period 1970-2009, and the results revealed the existence of cointegration and causality between taxation and economic growth. Seward (2008) provided an empirical study on the effects of taxes on economic growth in industrialized countries for the period 1965-1995, while the conclusions were that taxes are negatively correlated with economic growth.

According to Gale and Samwick (2014), a fair analysis would lead to the conclusion that well-designed fiscal policies have the potential to increase growth, but there are many obstacles along the way and there is certainly no guarantee that all changes will improve economic performance. Given the different channels through which fiscal policy affects growth, a growth-inducing fiscal policy would involve the following directions:

a) positive stimulation (substitution) effects that encourage work, savings and investment;

b) effects on revenues that are small, whether positive or negative, including a careful targeting of tax cuts to a new economic activity, rather than ensuring unforeseen gains for previous activities;

c) a reduction of distortions between economic sectors and between different types of income and types of consumption;

d) minimum increases of the budget deficit.

\section{STRUCTURAL EQUATION MODELING (SEM) - APPLIED METHODOLOGY}

Structural equation modeling is a multivariate statistical analysis technique which is used in order to analyze structural relationships. This technique is the combination of factor analysis and multiple regression analysis. On the other hand, it is used to analyze the structural relationship between measured variables and latent structures. This method estimates multiple and interrelated dependence based on a single analysis. In this analysis, two types of variables are used, namely endogenous variables and exogenous variables. Endogenous variables are equivalent to dependent variables and are equal to the independent variable.

The study period covers the period 2005-2017, aggregate data obtained from the official website of the European Commission and Eurostat. It is intended that the researcher first develops a theory-based model to perform the basic SEM analysis. It then determines how structures are measured, collects data, and enters them into the computer. The result of this analysis is usually the covariance matrix of the measured variables. The statistical-based methodological approach regarding modeling structural equations (SEM) is used to 
implement a form of non-experimental research, through which model hypotheses are tested. In this sense, the observed variables are used on the one hand, and the latent variables on the other hand. In order to determine to what extent the selected data fit, the hypotheses related to the model are subjected to a statistical test based on a system analysis. Structural equation modeling (SEM) reflects certain causal processes, providing an explanation for the following terms: error and probability.

Cleophas and Zwinderman (2015) stated that structural equation modeling (SEM) was defined relatively recently by Pearl (2000) in his paper "Causality, Reason, and Inference," Cambridge University Press, Cambridge UK. Pribeanu (2012) suggested that the process of estimating a particular model is often based on methods based on structural equations. Structural equation modeling (SEM) is also about building attitudinal and behavioral models that reflect complex relationships more accurately than using standard techniques based on multivariate statistics, using either an intuitive graphical or user-programmed interface. Catoiu et al. (2014) analyzed the issue of research methodology based on modeling structural equations (SEM). In this context, the authors suggested that if SEM is based on variance, basically it will no longer be possible to obtain compliance indicators. This situation is in opposition to the proposed approach through covariance methods, in which case the compliance indicators are characterized by a high diversity. Bojuwon et al. (2017) have conducted a research study based on structural equation modeling regarding the implications of online tax system, which implies the usage of information technology, in the case of selfemployed taxpayers in Nigeria.

Rigdon and Marcoulides (1998) highlighted that SEM analysis based on modeling structural equations is in fact a methodological construction of representation, estimation, and subsequent testing of linear and theoretical relationships between variables. On the other hand, it should be noted that a number of methodological similarities are identified between the modeling of structural equations (SEM) and certain techniques and statistical methods established as a traditional approach, such as: regression, variance or correlation analysis.

In order to analyze the statistical data underlying this empirical study, we used the SPSS and PLS programs. The primary data were obtained from the European Commission's official website as well as from the Eurostat website platform. The research method based on modeling structural equations was used to analyze the data and test the research hypotheses. Modeling structural equations is one of the statistical models for examining linear relationships between present (unobserved) and explicit (observed) variables. Through these techniques, researchers can accept or reject hypothetical structures, generally called (and less accurate) causal models, or adapt them to non-experimental data.

The following Figure no. 1 shows the sequence of basic stages of SEM implementation, as follows: 


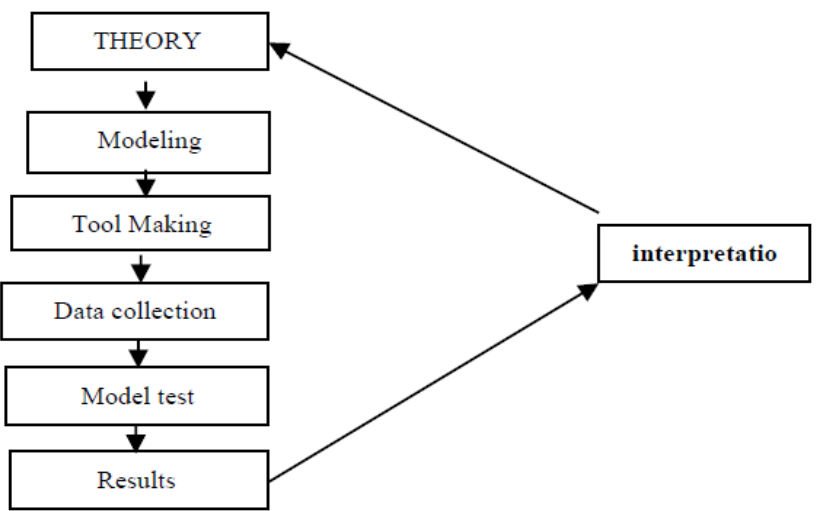

Figure no. 1 - Demonstrating the basic steps of SEM implementation

The general form of the structural equation model will be analyzed in the following paragraphs. In the structural equation model, we seek to determine whether the relationships between the present attributes extracted from the theory are confirmed by the data collected from the sample.

\section{EMPIRICAL ANALYSIS}

The relationships between variables in the structural equation model are divided into two general areas:

a) Relationships between hidden variables with explicit variables

b) Relationships between hidden variables and hidden variables

The first batch is called the measurement model and the second batch is called the structural model. The general form of the structural equation model is as follows:

- A structural model that specifies the causal structure between the present variables (theoretical structures that are not directly observable).

- A measurement model that defines the relationships between the measured variables or markers (variables that are directly observable) and the current variables for which they are estimated.

After expressing the model of the next step, we obtain the estimation of the free parameters from a set of observed data. Duplicate methods such as maximum magnification or generalized least squares are used to estimate the model. It is generally accepted that multivariate regression methods are resistant to violations of the normality of the error sentence distribution. The central limit theorem and the theory of large samples also allow the critical ratios ( $\mathrm{t}$ values) to approach the normal multivariate distribution.

\section{Research model estimation:}

Once the sample data is transformed into a correlation matrix or covariance and described by a set of regression equations, that model can be (using one of several available computer programs) to test its fit in the community from which the sample is derived. Analyzed. Provides estimates of the parameters of that model (path coefficients and error sentences) and several measures to fit it to the sample data. Figure no. 2 shows the standard models obtained using PLS software. 


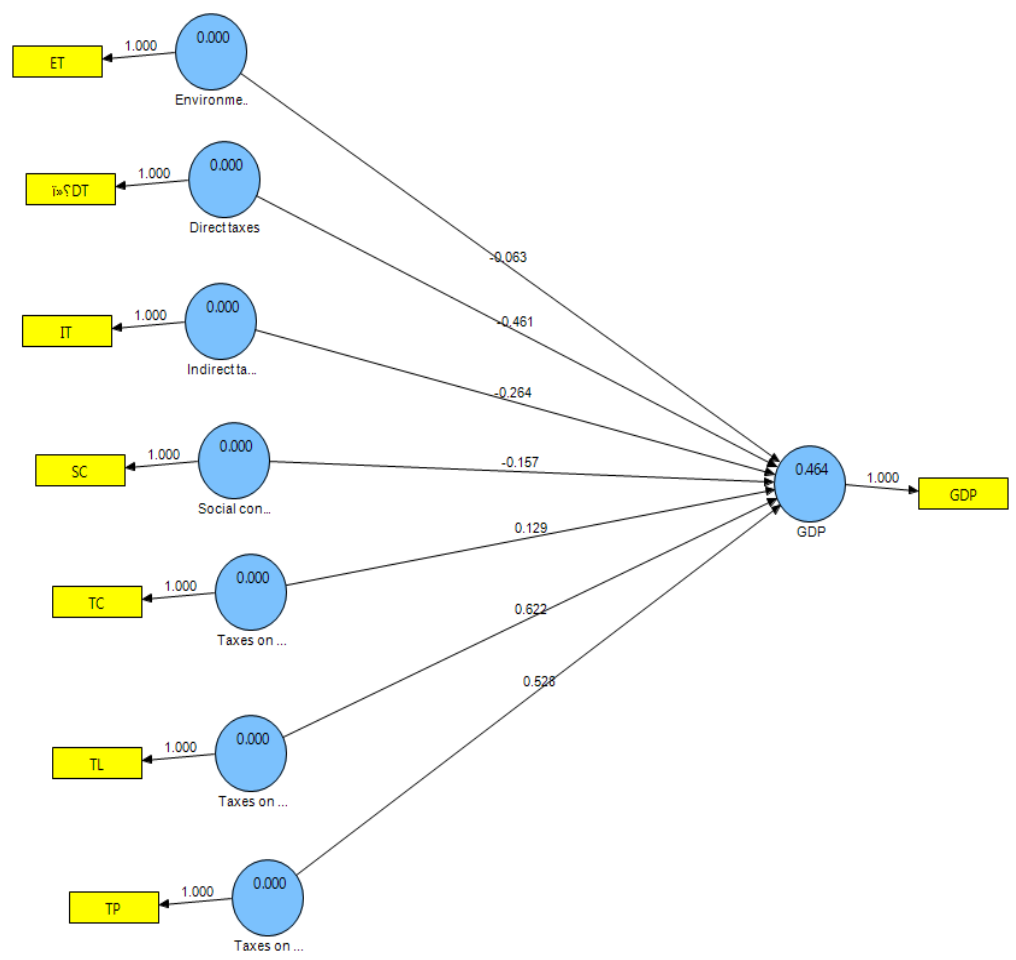

Figure no. 2 - Standardized coefficients model of research using PLS software

\section{Model Suitability Evaluation:}

After modeling and estimating its parameters, the first fundamental question that arises is whether the measurement model is a suitable measurement model or not. The answer to this question is only possible by examining the fit. Model fit is to what extent a model is consistent with the relevant data. When a model is precisely identified and has similar features, and it is possible to estimate and test it, then there are many ways to evaluate its suitability, the most important of which are:

- The criterion R2

R2 indicates the effect that an exogenous variable has on an endogenous variable. The quintessence represents the values of 0.2 and 0.5 as the criterion value for weak, medium and strong values of $\mathrm{R} 2$.

- The criterion Q2

If the value of Q2 for an endogenous construct is zero or less than zero, it indicates that the relationships between the other model structures and that endogenous construct are not well explained and therefore the model needs to be modified. In the present study, the calculated value for the R2 index is 0.46 , comparing it with the optimal value for a fitted model indicates that the model fits in well. The interesting thing about model fitting is that, while fitting the structural model to that model confirms, it never proves that the model is the only valid model. Henseler et al. (2009) defined the effect size as "the increase in R2 relative to the proportion of variance of the endogenous latent variable that remains unexplained". 
Cohen's effect size values are as follows: 0.02, 0.15, and 0.35 and suggest small, medium, and large effects, respectively (Cohen, 1988; Henseler et al., 2009). Moreover, these three values were established for the predictive power of the model in the case of endogenous structures. The guidelines for the size of Cohen effect were based on the idea that an average effect should be visible to the naked eye of a keen observer (Cohen, 1988). In addition, Cohen (1988, 1992) suggested that an average effect is approximately the effect observed on average in the literature in different disciplines. However, the Cohen effect size guidelines were mainly based on an essentially qualitative impression, rather than a systematic and quantitative analysis of the data (Gignac and Szodorai, 2016).

\section{EMPIRICAL RESULTS AND DISCUSSION}

\section{The results of the research hypotheses test:}

In this section, we examined the significance of the obtained model numbers. In terms of the significance of the numbers, it should be said that since we are looking at the confidence level of 0.95 or 0.05 error, the t-test will be significant. Be greater than -1.96 and +1.96 . That is, if the t-test had a number between -1.96 and +1.96 , it would be meaningless. In the following model (see Figure no. 3) the numbers obtained are significant for the t-test and can be investigated by examining the causal relationships (metrics with the present variable) and the effects (the present variable together) with respect to the items listed in the tables and diagrams above. The models are in good condition in terms of fitness indices.

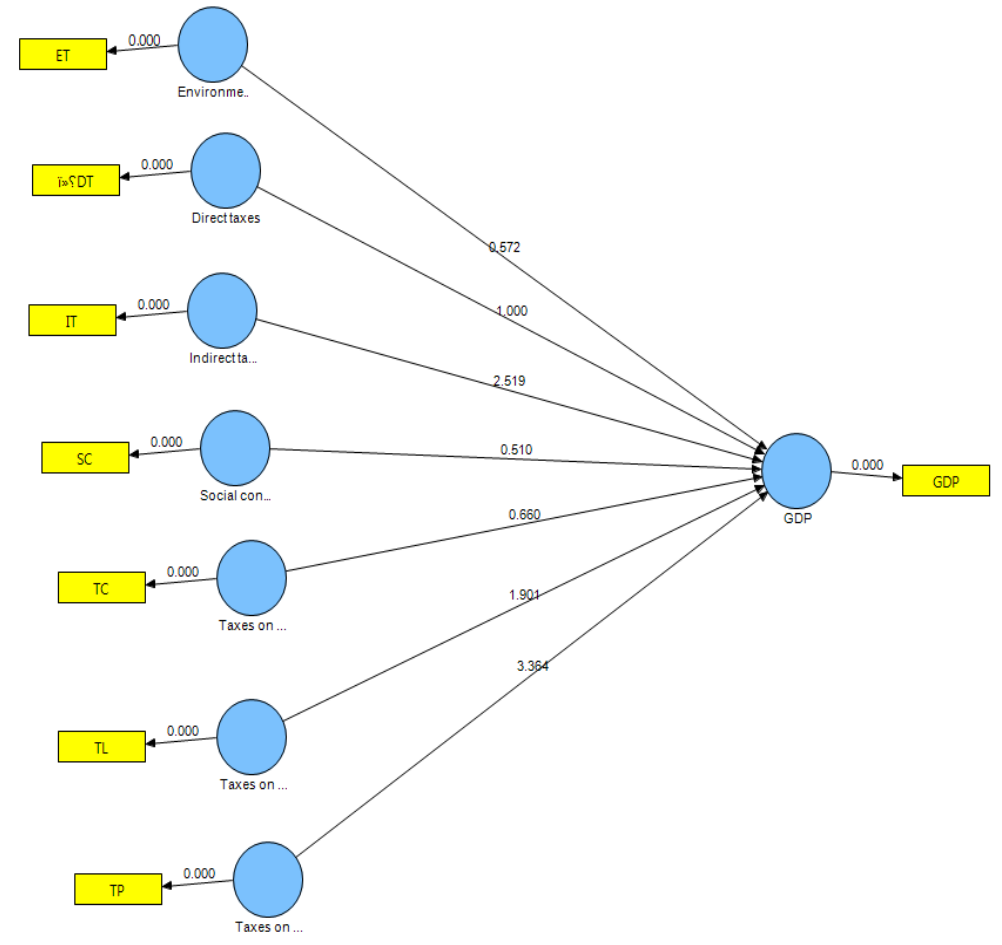

Figure no. 3 - Model with significant t-value 
Therefore, we consider the research hypotheses with respect to the model in meaningful numbers (see Figure no. 2) and the Standard Estimation Model (see Figure no. 3).

Hypothesis 1: Environmental taxes have a significant impact on GDP.

The results of the first hypothesis test are examined according to the information in Figure no. 2 and no. 3. path coefficient of environmental tax on GDP with t-value of 3.08 at the level of error 0.05 with confidence of 0.95 is not significant and consequently the hypothesis is rejected.

Path coefficients are standardized versions of linear regression weights, which can be used to examine possible causal links between statistical variables in Structural Equation Modeling (SEM).

Table no. 1 - Testing if environmental taxes have a significant impact on GDP

\begin{tabular}{cc}
\hline T-statistics & Standard coefficient \\
\hline 0.572 & 0.0637 \\
\hline \multicolumn{2}{c}{ Source: Own calculations }
\end{tabular}

\section{Hypothesis 2: Direct taxation has a significant impact on GDP.}

The results of the second hypothesis test are examined according to the information in Figure no. 2 and no. 3. The direct tax path coefficient on GDP with t-value equal to 3.08 at the level of error 0.05 with confidence of 0.95 is not significant and as a result the hypothesis is rejected.

Table no. 2 - Testing if direct taxation has a significant impact on GDP

\begin{tabular}{cc}
\hline T-statistics & Standard coefficient \\
\hline 1.00 & 0.461 \\
\hline \multicolumn{2}{c}{ Source: Own calculations }
\end{tabular}

Hypothesis 3: Indirect taxes have a significant impact on GDP.

The result of the third hypothesis test is examined according to the information in Figure no. 2 and no. 3. The indirect tax path coefficient on GDP with t-value of 3.08 at 0.05 level of error with confidence of 0.95 is statistically significant.

Table no. 3 - Testing if indirect taxes have a significant impact on GDP

\begin{tabular}{cc}
\hline T- statistics & Standard coefficient \\
\hline 2.519 & 0.289 \\
\hline \multicolumn{2}{c}{ Source: Own calculations }
\end{tabular}

Hypothesis 4: Social contributions have a significant impact on GDP.

The result of the fourth hypothesis test is examined according to the information in Figure no. 2 and no. 3. The social contributions path coefficient on GDP with t-value of 3.08 at the level of error 0.05 with confidence of 0.95 is not significant and consequently the hypothesis is rejected.

Table no. 4 - Testing if social contributions has a significant impact on GDP

\begin{tabular}{cc}
\hline T- statistics & Standard coefficient \\
\hline 0.510 & 0.157 \\
\hline \multicolumn{2}{c}{ Source: Own calculations }
\end{tabular}




\section{Hypothesis 5: Property tax has a significant impact on GDP.}

The results of the fifth hypothesis test are examined according to the information in Figure no. 2 and no. 3. The property tax path coefficient of GDP with t-value of 3.08 at the level of error 0.05 with confidence of 0.95 is not significant and consequently the hypothesis is rejected.

Table no. 5 - Testing if property tax has a significant impact on GDP

\begin{tabular}{cc}
\hline T- statistics & Standard coefficient \\
\hline 0.660 & 0.129 \\
\hline \multicolumn{2}{c}{ Source: Own calculations }
\end{tabular}

Hypothesis 6: Business taxes have a significant impact on GDP.

The result of the sixth hypothesis test is examined using the information in Figure no. 2 and no. 3. The path coefficient of business taxes on GDP with t-value of 3.08 at the level of error 0.05 with confidence of 0.95 is not significant and consequently the hypothesis is rejected.

Table no. 6 - Testing if business taxes have a significant impact on GDP

\begin{tabular}{cc}
\hline T- statistics & Standard coefficient \\
\hline 1.901 & 0.622 \\
\hline \multicolumn{2}{c}{ Source: Own calculations }
\end{tabular}

\section{Hypothesis 7: Capital tax has a significant effect on GDP.}

The results of the seventh hypothesis test are examined with respect to the information in Figure no. 2 and no. 3. The path coefficient of capital tax on GDP with t-value of 3.08 at 0.05 level of error with confidence of 0.95 is statistically significant.

Table no. 7 - Testing if capital tax has a significant effect on GDP

\begin{tabular}{cc}
\hline T- statistics & Standard coefficient \\
\hline 3.364 & 0.528 \\
\hline \multicolumn{2}{c}{ Source: Own calculations }
\end{tabular}

Table no. 8 - Measurement of the Model Specification

\begin{tabular}{crrrrrrr}
\hline ET & GDP & IT & SC & TC & TL & TP & DT \\
\hline 2.197990 & 393021.575000 & 13.216846 & 13.892492 & 9.904163 & 23.520472 & 3.294952 & 16.973748 \\
\hline 2.851126 & 42987.275000 & 15.388713 & 7.650058 & 4.293126 & 9.553820 & 0.697232 & 5.581241 \\
\hline 2.236295 & 165769.183300 & 11.691082 & 14.698712 & 5.598600 & 17.198821 & 0.511196 & 7.581441 \\
\hline 4.173252 & 260522.833300 & 16.704607 & 0.079841 & 7.861450 & 23.503112 & 2.554826 & 29.714685 \\
\hline 2.103847 & 2832279.167000 & 10.874914 & 15.099055 & 6.071507 & 21.410383 & 0.916468 & 11.847425 \\
\hline 2.622318 & 19041.058330 & 13.783093 & 11.206400 & 2.558351 & 16.430441 & 0.370171 & 7.151169 \\
\hline 2.268856 & 216576.008300 & 11.023825 & 4.474597 & 6.773941 & 11.373586 & 1.745962 & 12.282294 \\
\hline 2.930545 & 201205.975000 & 14.083559 & 10.719626 & 7.586776 & 14.217322 & 2.660345 & 9.408847 \\
\hline 1.762178 & 1085831.750000 & 11.132100 & 11.780873 & 8.261814 & 16.329099 & 2.605128 & 10.836951 \\
\hline 2.008217 & 2113357.667000 & 15.446767 & 16.406126 & 10.390891 & 22.742093 & 3.946953 & 12.506111 \\
\hline
\end{tabular}




\begin{tabular}{|c|c|c|c|c|c|c|c|}
\hline ET & GDP & IT & SC & TC & TL & $\mathbf{T P}$ & DT \\
\hline 3.074477 & 45829.608330 & 18.369647 & 11.683669 & 4.367534 & 14.573390 & 0.512209 & 6.576351 \\
\hline 3.107753 & 1650609.517000 & 14.556389 & 12.734775 & 10.154446 & 20.929535 & 2.262899 & 14.522785 \\
\hline 2.925154 & 18934.225000 & 15.102013 & 7.777605 & 9.005808 & 10.926418 & 1.446530 & 9.939916 \\
\hline 2.897816 & 23163.583330 & 12.789622 & 8.379014 & 3.500566 & 13.862965 & 1.060541 & 7.892993 \\
\hline 1.826553 & 34705.941670 & 11.694848 & 10.834161 & 4.150501 & 13.688438 & 0.531328 & 6.384020 \\
\hline 2.291642 & 46655.241670 & 12.637360 & 10.758971 & 11.034216 & 16.236881 & 1.436312 & 14.228132 \\
\hline 2.629928 & 108326.483300 & 17.241667 & 12.820103 & 5.465606 & 17.924205 & 1.034827 & 8.024050 \\
\hline 2.978698 & 8209.866667 & 13.498325 & 5.623208 & 8.790500 & 10.720734 & 1.136295 & 12.902585 \\
\hline 3.393326 & 673022.916700 & 11.585409 & 13.553368 & 5.706797 & 19.442476 & 1.453131 & 11.125361 \\
\hline 2.397047 & 325424.591700 & 14.352835 & 14.119978 & 6.832715 & 23.291325 & 0.732289 & 13.212339 \\
\hline 2.630671 & 396245.108300 & 13.684544 & 11.987148 & 7.916451 & 12.725720 & 1.554958 & 7.187949 \\
\hline 2.484537 & 180299.800000 & 14.197075 & 8.662614 & 7.037911 & 13.319671 & 1.886766 & 9.554150 \\
\hline 2.033059 & 150460.425000 & 12.181747 & 8.849916 & 4.671218 & 10.927351 & 0.829241 & 6.082590 \\
\hline 3.516804 & 38414.966670 & 14.632928 & 14.338911 & 4.353548 & 18.821759 & 0.618087 & 7.960888 \\
\hline 1.901224 & 73747.450000 & 10.844778 & 12.724422 & 4.369336 & 15.459667 & 0.421252 & 6.460014 \\
\hline 2.861255 & 204226.500000 & 13.700226 & 12.158285 & 6.996856 & 21.857406 & 1.230515 & 16.608339 \\
\hline 2.435877 & 415631.366700 & 22.340691 & 2.766191 & 6.116529 & 25.658856 & 1.145702 & 18.783584 \\
\hline 2.378385 & 2179704.267000 & 12.289712 & 6.260647 & 9.925183 & 13.037611 & 4.154876 & 14.860048 \\
\hline
\end{tabular}

The acronyms found in the table above are as follows: a) ET (Environmental taxes); b) GDP (Gross Domestic Product); c) IT (Indirect taxes); d) SC (Social contributions); e) TC (Taxes on capital); f) TL (Taxes on labor); g) TP (Taxes on property); h) DT (Direct taxes).

Table no. 9 - Structural Model Specification

\begin{tabular}{|c|c|c|c|c|c|c|}
\hline & AVE & $\begin{array}{l}\text { Composite } \\
\text { Reliability }\end{array}$ & $\begin{array}{c}\mathbf{R} \\
\text { Square }\end{array}$ & $\begin{array}{c}\text { Cronbachs } \\
\text { Alpha }\end{array}$ & Communality & Redundancy \\
\hline Taxes on labor & 1.000000 & 1.000000 & & 1.000000 & 1.000000 & \\
\hline Direct taxes & 1.000000 & 1.000000 & & 1.000000 & 1.000000 & \\
\hline $\begin{array}{c}\text { Environmental } \\
\text { taxes }\end{array}$ & 1.000000 & 1.000000 & & 1.000000 & 1.000000 & \\
\hline GDP & 1.000000 & 1.000000 & 0.463769 & 1.000000 & 1.000000 & 0.024921 \\
\hline Indirect taxes & 1.000000 & 1.000000 & & 1.000000 & 1.000000 & \\
\hline $\begin{array}{c}\text { Social } \\
\text { contributions }\end{array}$ & 1.000000 & 1.000000 & & 1.000000 & 1.000000 & \\
\hline Taxes on capital & 1.000000 & 1.000000 & & 1.000000 & 1.000000 & \\
\hline $\begin{array}{l}\text { Taxes on } \\
\text { property }\end{array}$ & 1.000000 & 1.000000 & & 1.000000 & 1.000000 & \\
\hline
\end{tabular}


Cronbach's alpha is the most common measure of internal consistency (reliability). It is the most commonly used indicator when there are several Likert questions in a survey / questionnaire that form a scale and it is desired to determine whether the scale is reliable. In most cases, the value of the Cronbach's alpha coefficient tends to increase as the number of items involved in the empirical analysis increases. The Cronbach's alpha coefficient is a measure used to assess the reliability or internal consistency of a set of scales or test items. In other words, the reliability of any given measurement refers on how it is a consistent measure of a concept, and Cronbach alfa is a way of measuring the intensity of this consistency. Many bibliographic sources claim that a value of Cronbach's alpha coefficient above 0.70 is acceptable. However, a value of 0.80 or higher is preferable (Cortina, 1993). As can be seen in the table above, we obtained the value of the Cronbach's alpha coefficient equal to 1 . Note the approach of McNemar (1946) who argued that "any measurement is affected by error", so it is practically a statistical improbability to obtain an accuracy absolute results.

Table no. 10 - Calculation of redundancy in relation to model variables

\begin{tabular}{l}
\hline \\
\hline Taxes on labor \\
\hline Direct taxes \\
\hline Environmental taxes \\
\hline GDP \\
\hline Indirect taxes \\
\hline Social contributions \\
\hline Taxes on capital \\
\hline Taxes on property \\
\hline Source: Own calculations
\end{tabular}

Sarstedt et al. (2018) used the technique based on modeling structural equations to estimate different models. Their validation requires a redundancy analysis, which tests whether the formatively measured construct is strongly correlated with an alternative measure of the same construct. An alternative model focuses on constructs that are measured formatively. As a further explanation, we must consider the existence of two main categories of variables, namely: latent variables or constructs that cannot be measured directly, as well as the observed variables that most are known as items or indicators and can be measured directly. In the context of establishing validity, it is very important to mention that the aspects regarding the internal consistency of the scale, as well as the one-dimensionality, cannot be considered to be applicable in the case of some formative models.

In Table no. 11 we have included the empirical results regarding the correlation relationship between the latent variables. 
Table no. 11 - Latent variable correlations

\begin{tabular}{|c|c|c|c|c|c|c|c|c|}
\hline & 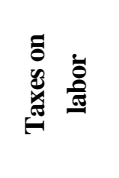 & 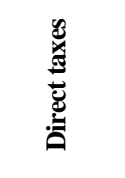 & 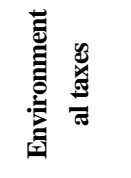 & ชิ & 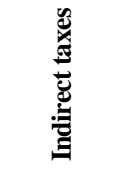 & 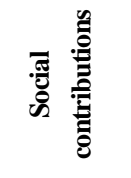 & 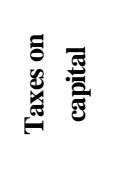 & 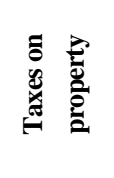 \\
\hline Taxes on labor & 1.000000 & & & & & & & \\
\hline Direct taxes & 0.616912 & 1.000000 & & & & & & \\
\hline Environmental taxes & 0.112335 & 0.368856 & 1.000000 & & & & & \\
\hline GDP & 0.331080 & 0.222308 & -0.239321 & 1.000000 & & & & \\
\hline Indirect taxes & 0.339784 & 0.293596 & 0.392966 & -0.173392 & 1.000000 & & & \\
\hline Social contributions & 0.252145 & -0.459435 & -0.324898 & 0.261521 & -0.323330 & 1.000000 & & \\
\hline Taxes on capital & 0.198397 & 0.491991 & -0.033511 & 0.544056 & -0.019028 & -0.096809 & 1.000000 & \\
\hline Taxes on property & 0.194682 & 0.533476 & -0.045193 & 0.416377 & -0.013061 & -0.037741 & 0.758971 & 1.000000 \\
\hline
\end{tabular}

Table no. 12 - Calculation of R-Square

\begin{tabular}{l}
\hline \multicolumn{2}{c}{ R-Square } \\
\hline Taxes on labor \\
\hline Direct taxes \\
\hline Environmental taxes \\
\hline GDP \\
\hline Indirect taxes \\
\hline Social contributions \\
\hline Taxes on capital \\
\hline Taxes on property \\
\hline Source: Own calculations
\end{tabular}

On the other hand, R2 (R-square) quantifies the variation of the dependent variable which is explained using independent variables based on a regression model. This is a statistical measure that is used for the main purpose of verifying the proximity of the data to the regression line. Thus, in the Table no. 12 we have the calculation related to R2 in the case of the chosen model. As can be seen, the value obtained for $\mathrm{R} 2$ is about 0.46 . As a representative statistical measure, $\mathrm{R} 2$ oscillates between a minimum limit, respectively the value 0 and a maximum limit, respectively the value 1 . The closer the value obtained is to the value 0 , the lower the degree of adjustment (adequacy) of the model. On the other hand, a value of R2 closer to 1, expresses a high adequacy of the estimated model. Specifically, in our case, R-square is equal to 0.46 which can be interpreted from a statistical point of view as follows: $46 \%$ of the variations of the dependent variable GDP are explained based on the independent variables included in the model, respectively: labor taxes, direct taxes, environmental taxes, indirect taxes, social security contributions, capital taxes and property taxes. 
Table no. 13 - Cross Loadings

\begin{tabular}{ccccccccc}
\hline & $\begin{array}{c}\text { Taxes on } \\
\text { labor }\end{array}$ & $\begin{array}{c}\text { Direct } \\
\text { taxes }\end{array}$ & $\begin{array}{c}\text { Environmental } \\
\text { taxes }\end{array}$ & GDP & $\begin{array}{c}\text { Indirect } \\
\text { taxes }\end{array}$ & $\begin{array}{c}\text { Social } \\
\text { contributions }\end{array}$ & $\begin{array}{c}\text { Taxes on } \\
\text { capital }\end{array}$ & $\begin{array}{c}\text { Taxes on } \\
\text { property }\end{array}$ \\
\hline ET & 0.112335 & 0.368856 & 1.000000 & -0.239321 & 0.392966 & -0.324898 & -0.033511 & -0.045193 \\
\hline GDP & 0.331080 & 0.222308 & -0.239321 & 1.000000 & -0.173392 & 0.261521 & 0.544056 & 0.416377 \\
\hline IT & 0.339784 & 0.293596 & 0.392966 & -0.173392 & 1.000000 & -0.323330 & -0.019028 & -0.013061 \\
\hline SC & 0.252145 & -0.459435 & -0.324898 & 0.261521 & -0.323330 & 1.000000 & -0.096809 & -0.037741 \\
\hline TC & 0.194682 & 0.533476 & -0.045193 & 0.416377 & -0.013061 & -0.037741 & 0.758971 & 1.000000 \\
\hline TL & 1.000000 & 0.616912 & 0.112335 & 0.331080 & 0.339784 & 0.252145 & 0.198397 & 0.194682 \\
\hline TP & 0.198397 & 0.491991 & -0.033511 & 0.544056 & -0.019028 & -0.096809 & 1.000000 & 0.758971 \\
\hline DT & 0.616912 & 1.000000 & 0.368856 & 0.222308 & 0.293596 & -0.459435 & 0.491991 & 0.533476 \\
\hline \multicolumn{7}{c}{ Source: Own calculations } \\
\end{tabular}

If the indicators cause the latent variable and are not interchangeable, they are formative. In general, these formative indicators may have positive or negative correlations or even no correlations between them. Composite Reliability is a measure to quantify internal reliability. This facilitates the assessment of the reliability of the construct. Moreover, composite reliability is the measure or degree to which one or more variables show a certain coherence with respect to the assumed objective. According to Hair et al. (2014) the value of the composite reliability used in the SEM analysis should exceed the minimum threshold of 0.7. However, in the case of this research study, the values obtained in the case of our study respect this fundamental condition, being obtained the value 1.0.

Table no. 14 - Outer Loadings

\begin{tabular}{|c|c|c|c|c|c|c|c|c|}
\hline & $\begin{array}{c}\text { Taxes on } \\
\text { labor }\end{array}$ & $\begin{array}{c}\text { Direct } \\
\text { taxes }\end{array}$ & $\begin{array}{c}\text { Environmental } \\
\text { taxes }\end{array}$ & GDP & $\begin{array}{c}\text { Indirect } \\
\text { taxes }\end{array}$ & $\begin{array}{c}\text { Social } \\
\text { contributions }\end{array}$ & $\begin{array}{c}\text { Taxes on } \\
\text { capital }\end{array}$ & $\begin{array}{l}\text { Taxes on } \\
\text { property }\end{array}$ \\
\hline ET & & & 1.000000 & & & & & \\
\hline GDP & & & & 1.000000 & & & & \\
\hline IT & & & & & 1.000000 & & & \\
\hline SC & & & & & & 1.000000 & & \\
\hline TC & & & & & & & & 1.000000 \\
\hline TL & 1.000000 & & & & & & & \\
\hline TP & & & & & & & 1.000000 & \\
\hline DT & & 1.000000 & & & & & & \\
\hline
\end{tabular}

From a methodological point of view, the SEM analysis initially analyzes the number of iterations from the report on the stop criterion (number of rows). If the number of iterations was less than the defined maximum number of iterations, the algorithm stopped due to the stop criterion. Specifically, in the case of SEM analysis, the software will stop estimating when (i) the algorithm stop criterion has been achieved or (ii) the maximum number of iterations has been reached, whichever is the earlier. Because we intend to obtain a stable estimate, we want the algorithm to converge before reaching the maximum number of iterations (Kwong-Kay Wong, 2013). 
Table no. 15 - Analyzing Path Coefficients

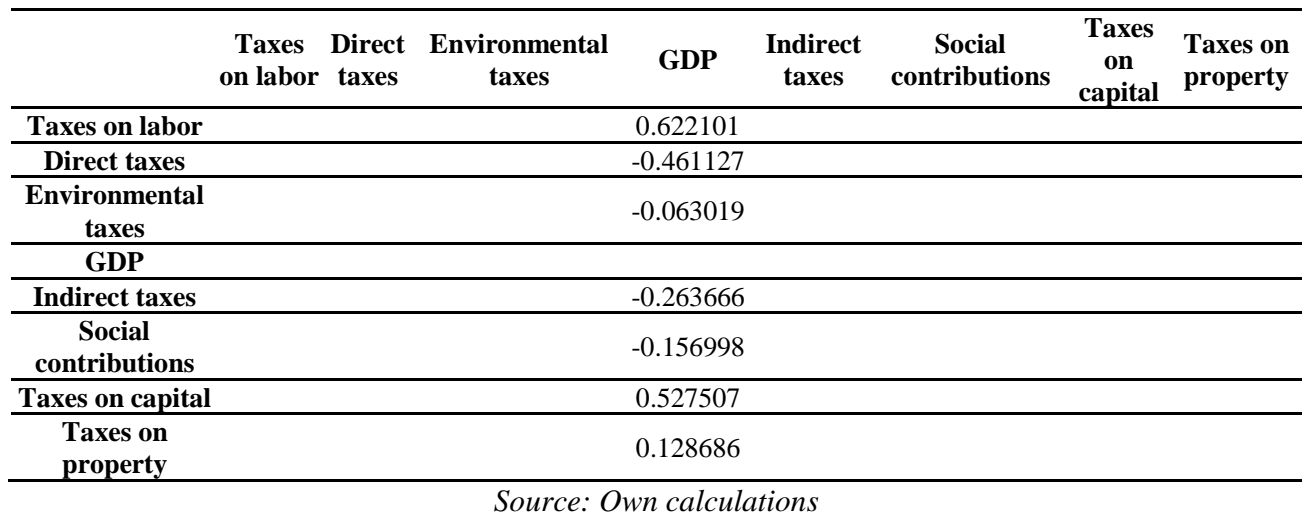

Regarding the Outer Model (Weights or Loadings), we need to make some important clarifications. There are two submodels in a structural equation model (SEM). The inner model specifies the relationships between independent and dependent latent variables, while the outer model specifies the relationships between latent variables and their observed indicators. The outer model is also known as the measurement model. On the other hand, the inner model is known as the structural model. In the Table no. 15 we presented the values of the trajectory coefficients in the case of the estimated model. The trajectory coefficients (path) explain how strong the effect of one variable is on another variable. In other words, we calculated the impact of each category of tax or duties from those selected, on GDP. The weight of the different trajectory coefficients allows us to classify their relative statistical importance.

Table no. 16 - Latent Variable Scores

\begin{tabular}{ccccccccc}
\hline $\begin{array}{l}\text { Taxes on } \\
\text { labor }\end{array}$ & $\begin{array}{c}\text { Direct } \\
\text { taxes }\end{array}$ & $\begin{array}{c}\text { Environmental } \\
\text { taxes }\end{array}$ & GDP & $\begin{array}{c}\text { Indirect } \\
\text { taxes }\end{array}$ & $\begin{array}{c}\text { Social } \\
\text { contributions }\end{array}$ & $\begin{array}{c}\text { Taxes on } \\
\text { capital }\end{array}$ & $\begin{array}{c}\text { Taxes on } \\
\text { property }\end{array}$ \\
\hline 1.475180 & 1.123451 & -0.744216 & -0.138791 & -0.270110 & 0.895245 & 1.719790 & 1.372970 \\
\hline-1.578948 & -1.129385 & 0.452262 & -0.607919 & 0.595618 & -0.718781 & -0.806908 & -1.088859 \\
\hline 0.092806 & -0.733851 & -0.674044 & -0.443363 & -0.878295 & 1.103699 & -0.987858 & -0.516085 \\
\hline 1.471384 & 3.642935 & 2.874260 & -0.316371 & 1.120147 & -2.676115 & 0.999899 & 0.476735 \\
\hline 1.013761 & 0.109735 & -0.916675 & 3.130389 & -1.203628 & 1.207211 & -0.593666 & -0.308598 \\
\hline-0.075217 & -0.818936 & 0.033109 & -0.640013 & -0.044398 & 0.200737 & -1.125027 & -1.849987 \\
\hline-1.181014 & 0.195729 & -0.614395 & -0.375270 & -1.144270 & -1.539819 & 0.213149 & -0.000407 \\
\hline-0.559166 & -0.372487 & 0.597750 & -0.395869 & 0.075371 & 0.074878 & 1.102533 & 0.356222 \\
\hline-0.097378 & -0.090083 & -1.542578 & 0.789738 & -1.101111 & 0.349271 & 1.048825 & 0.652393 \\
\hline 1.304970 & 0.239988 & -1.091859 & 2.166865 & 0.618759 & 1.545163 & 2.353965 & 1.586521 \\
\hline-0.481304 & -0.932605 & 0.861418 & -0.604110 & 1.783848 & 0.324138 & -0.986873 & -1.056213 \\
\hline 0.908612 & 0.638780 & 0.922376 & 1.546673 & 0.263845 & 0.595909 & 0.715954 & 1.482781 \\
\hline-1.278798 & -0.267470 & 0.587874 & -0.640156 & 0.481336 & -0.685803 & -0.078095 & 0.978819 \\
\hline-0.636655 & -0.672243 & 0.537793 & -0.634488 & -0.440406 & -0.530304 & -0.453532 & -1.436592 \\
\hline
\end{tabular}




\begin{tabular}{cccccccc}
\hline $\begin{array}{l}\text { Taxes on } \\
\text { labor }\end{array}$ & $\begin{array}{c}\text { Direct } \\
\text { taxes }\end{array}$ & $\begin{array}{c}\text { Environmental } \\
\text { taxes }\end{array}$ & GDP & $\begin{array}{c}\text { Indirect } \\
\text { taxes }\end{array}$ & $\begin{array}{c}\text { Social } \\
\text { contributions }\end{array}$ & $\begin{array}{c}\text { Taxes on } \\
\text { capital }\end{array}$ & $\begin{array}{c}\text { Taxes on } \\
\text { property }\end{array}$ \\
\hline-0.674819 & -0.970638 & -1.424649 & -0.619018 & -0.876794 & 0.104492 & -0.968276 & -1.151435 \\
\hline-0.117544 & 0.580513 & -0.572654 & -0.603003 & -0.501099 & 0.085051 & -0.088034 & 1.868778 \\
\hline 0.251428 & -0.646327 & 0.047050 & -0.520349 & 1.334224 & 0.617971 & -0.478543 & -0.574436 \\
\hline-1.323775 & 0.318390 & 0.685960 & -0.654529 & -0.157910 & -1.242838 & -0.379849 & 0.884353 \\
\hline 0.583433 & -0.033051 & 1.445516 & 0.236477 & -0.920417 & 0.807562 & -0.071676 & -0.468614 \\
\hline 1.425072 & 0.379643 & -0.379564 & -0.229387 & 0.182707 & 0.954063 & -0.772810 & 0.025380 \\
\hline-0.885339 & -0.811663 & 0.048412 & -0.134471 & -0.083681 & 0.402605 & 0.027368 & 0.500866 \\
\hline-0.755458 & -0.343754 & -0.219291 & -0.423888 & 0.120619 & -0.456977 & 0.350104 & 0.115409 \\
\hline-1.278594 & -1.030245 & -1.046351 & -0.463880 & -0.682711 & -0.408549 & -0.678508 & -0.922972 \\
\hline 0.447699 & -0.658817 & 1.671715 & -0.614047 & 0.294354 & 1.010670 & -0.883890 & -1.062349 \\
\hline-0.287499 & -0.955611 & -1.287859 & -0.566694 & -1.215640 & 0.593232 & -1.075343 & -1.055422 \\
\hline 1.111513 & 1.051192 & 0.470818 & -0.391821 & -0.077430 & 0.446854 & -0.288205 & 0.097396 \\
\hline 1.942786 & 1.481340 & -0.308431 & -0.108489 & 3.366747 & -1.981540 & -0.370699 & -0.288845 \\
\hline-0.817137 & 0.705472 & -0.413751 & 2.255785 & -0.639675 & -1.078023 & 2.556204 & 1.382192 \\
\hline & & Source: Own calculations & & &
\end{tabular}

A potential lack of consistency of scores on latent variables can lead to truncated estimation of components, loads and trajectory coefficients (path). In the case of SEM analysis, it is not necessary to report the reliability of the indicator, the internal reliability of the consistency and the discriminant validity if a formative measurement scale is used. This is because the external loads, the reliability of the composite and the square root of the extracted average variance (AVE) do not make sense for a latent variable consisting of uncorrelated measures. Each of the external loads will be squared in order to find the value of the indicator's reliability. In the case of external loads, a value equal to 0.70 or higher is preferable. If it is an exploratory research, a value equal to 0.4 or higher is considered acceptable (Hulland, 1999). We obtained the value 1.0 for this indicator, which validates its reliability and statistical compliance.

Table no. 17 - Manifest Variable Scores (Used)

\begin{tabular}{rrrrrrrr}
\hline ET & GDP & IT & SC & TC & TL & TP & DT \\
\hline-0.744216 & -0.138791 & -0.270110 & 0.895245 & 1.372970 & 1.475180 & 1.719790 & 1.123451 \\
\hline 0.452262 & -0.607919 & 0.595618 & -0.718781 & -1.088859 & -1.578948 & -0.806908 & -1.129385 \\
\hline-0.674044 & -0.443363 & -0.878295 & 1.103699 & -0.516085 & 0.092806 & -0.987858 & -0.733851 \\
\hline 2.874260 & -0.316371 & 1.120147 & -2.676115 & 0.476735 & 1.471384 & 0.999899 & 3.642935 \\
\hline-0.916675 & 3.130389 & -1.203628 & 1.207211 & -0.308598 & 1.013761 & -0.593666 & 0.109735 \\
\hline 0.033109 & -0.640013 & -0.044398 & 0.200737 & -1.849987 & -0.075217 & -1.125027 & -0.818936 \\
\hline-0.614395 & -0.375270 & -1.144270 & -1.539819 & -0.000407 & -1.181014 & 0.213149 & 0.195729 \\
\hline 0.597750 & -0.395869 & 0.075371 & 0.074878 & 0.356222 & -0.559166 & 1.102533 & -0.372487 \\
\hline & & & & & & &
\end{tabular}




\begin{tabular}{rrrrrrrr}
\hline ET & GDP & IT & SC & TC & TL & TP & DT \\
\hline-1.542578 & 0.789738 & -1.101111 & 0.349271 & 0.652393 & -0.097378 & 1.048825 & -0.090083 \\
\hline-1.091859 & 2.166865 & 0.618759 & 1.545163 & 1.586521 & 1.304970 & 2.353965 & 0.239988 \\
\hline 0.861418 & -0.604110 & 1.783848 & 0.324138 & -1.056213 & -0.481304 & -0.986873 & -0.932605 \\
\hline 0.922376 & 1.546673 & 0.263845 & 0.595909 & 1.482781 & 0.908612 & 0.715954 & 0.638780 \\
\hline 0.587874 & -0.640156 & 0.481336 & -0.685803 & 0.978819 & -1.278798 & -0.078095 & -0.267470 \\
\hline 0.537793 & -0.634488 & -0.440406 & -0.530304 & -1.436592 & -0.636655 & -0.453532 & -0.672243 \\
\hline-1.424649 & -0.619018 & -0.876794 & 0.104492 & -1.151435 & -0.674819 & -0.968276 & -0.970638 \\
\hline-0.572654 & -0.603003 & -0.501099 & 0.085051 & 1.868778 & -0.117544 & -0.088034 & 0.580513 \\
\hline 0.047050 & -0.520349 & 1.334224 & 0.617971 & -0.574436 & 0.251428 & -0.478543 & -0.646327 \\
\hline 0.685960 & -0.654529 & -0.157910 & -1.242838 & 0.884353 & -1.323775 & -0.379849 & 0.318390 \\
\hline 1.445516 & 0.236477 & -0.920417 & 0.807562 & -0.468614 & 0.583433 & -0.071676 & -0.033051 \\
\hline-0.379564 & -0.229387 & 0.182707 & 0.954063 & 0.025380 & 1.425072 & -0.772810 & 0.379643 \\
\hline 0.048412 & -0.134471 & -0.083681 & 0.402605 & 0.500866 & -0.885339 & 0.027368 & -0.811663 \\
\hline-0.219291 & -0.423888 & 0.120619 & -0.456977 & 0.115409 & -0.755458 & 0.350104 & -0.343754 \\
\hline-1.046351 & -0.463880 & -0.682711 & -0.408549 & -0.922972 & -1.278594 & -0.678508 & -1.030245 \\
\hline 1.671715 & -0.614047 & 0.294354 & 1.010670 & -1.062349 & 0.447699 & -0.883890 & -0.658817 \\
\hline-1.287859 & -0.566694 & -1.215640 & 0.593232 & -1.055422 & -0.287499 & -1.075343 & -0.955611 \\
\hline 0.470818 & -0.391821 & -0.077430 & 0.446854 & 0.097396 & 1.111513 & -0.288205 & 1.051192 \\
\hline-0.308431 & -0.108489 & 3.366747 & -1.981540 & -0.288845 & 1.942786 & -0.370699 & 1.481340 \\
\hline-0.413751 & 2.255785 & -0.639675 & -1.078023 & 1.382192 & -0.817137 & 2.556204 & 0.705472 \\
\hline & & & 5 & & & &
\end{tabular}

\section{Source: Own calculations}

In order to rigorously perform SEM analysis, it is essential to establish the reliability and validity of latent variables in order to complete the examination of the structural model.

Table no. 18 - Index Values for Latent Variables

\begin{tabular}{cc}
\hline & LV Index Values \\
\hline Taxes on labor & 16.774413 \\
\hline Direct taxes & 11.292500 \\
\hline Environmental taxes & 2.604244 \\
\hline GDP & 496578.726831 \\
\hline Indirect taxes & 13.894476 \\
\hline Social contributions & 10.430027 \\
\hline Taxes on capital & 1.526821 \\
\hline Taxes on property & 6.774869 \\
\hline \multicolumn{2}{c}{ Source: }
\end{tabular}

Source: Own calculations

The 28 Member States of the European Union used in this empirical study are the following, in the context of reporting the 28 cases mentioned in the Table no. 19 (see Annexes): 
Belgium (case 1), Bulgaria (case 2), Czech Republic (case 3), Denmark (case 4), Germany (case 5), Estonia (case 6), Ireland (case 7), Greece (case 8), Spain (case 9), France (case 10), Croatia (case 11), Italy (case 12), Cyprus (case 13), Latvia (case 14), Lithuania (case 15), Luxembourg (case 16), Hungary (case 17), Malta (case 18), Netherlands (case 19), Austria (case 20), Poland (case 21), Portugal (case 22), Romania (case 23), Slovenia (case 24), Slovakia (case 25), Finland (case 26), Sweden (case 27), United Kingdom (case 28).

\section{CONCLUSIONS, LIMITATIONS AND FUTURE RESEARCH}

Contemporary fiscal policies pursue many policy objectives. Taxation is intended to raise the necessary funds for public spending, to redistribute revenue, to stabilize the economy, to overcome externalities, to influence the allocation of resources, but at the same time it should support economic growth. The purpose of effectively designed taxation is to achieve the objectives of the desired fiscal policy (allocation, redistribution and stabilization) in the most efficient way, namely by limiting undesirable distortions, minimizing the costs of tax collection and promoting economic growth. The efficiency of taxation and in particular the tax structure play an important role in achieving economic growth and fiscal consolidation.

Our empirical findings provide new evidence on the effects of tax revenue on GDP dynamics at EU-28 level using structural equation modeling (SEM). This empirical study combines advanced modeling methods and techniques of high accuracy in order to identify the extent to which certain taxes influence the evolution of GDP at EU-28 level. Thus, from the analysis of the way in which the selected categories of taxes, respectively: labor taxes, direct taxes, environmental taxes, indirect taxes, social contributions, capital taxes and property taxes, affect the evolution of economic growth we reached some important conclusions. Regarding the relevance and accuracy of our empirical results, we mention the use of advanced techniques used to perform financial modeling. Structural Equation Modeling (SEM) is a multivariate method of analyzing second-generation data that is often used in marketing research because it can test linear causal models and theoretically supported additives. Empirical results show that the level of taxation significantly influences the evolution of GDP at EU-28 level.

One of the major limitations of this empirical research study is the time interval analyzed, ie only 2005-2017 for each member states of EU-28, due to the unavailability to obtain the related information for the period 2018-2020. Thus we could not analyze the impact of the COVID - 19 pandemic or of BREXIT, aspects that we intend to examine in a future research study. Also, in a future study we intend to use hybrid research methods, including techniques based on artificial intelligence.

\section{ORCID}

Cristi Spulbar iD http://orcid.org/0000-0002-3909-9496

Mohammad Ehsanifar (iD http://orcid.org/0000-0001-9817-0881

Ramona Birau (iD http://orcid.org/0000-0003-1638-4291 


\section{References}

Arnold, J. M., 2008. Do Tax Structures Affect Aggregate Economic Growth?: Empirical Evidence from a Panel of OECD Countries. OECD Economics Department Working Papers, 643. http://dx.doi.org/10.1787/236001777843

Asllani, G., and Statovci, B., 2018. Effect of the Change in Value Added Tax on the Fiscal Stability of Kosovo. Croatian Economic Association Zagreb, 656, 513-540. http://dx.doi.org/10.32910/ep.69.4.4

Auerbach, A. J., and Smetters, K. A., 2017. The economics of tax policy: Oxford University Press http://dx.doi.org/10.1093/acprof:oso/9780190619725.001.0001

Babatunde, O. A., Ibukun, A. O., and Oyeyemi, O. G., 2017. Taxation revenue and economic growth in Africa. Journal of Accounting and Taxation, 9(2), 11-22. http://dx.doi.org/10.5897/JAT2016.0236

Bojuwon, M., Abidoye, M. K., and Agbaje, A. G., 2017. The application of structural equation modeling on the usage of online tax system among self-employed taxpayers in Nigeria. Osogbo Journal of Management OJM, 22, 18-36.

Castro, G. A., and Camarillo, D. B. R., 2014. Determinants of tax revenue in OECD countries over the period 2001-2011. Contaduria y Administracion, 593, 35-59. http://dx.doi.org/10.1016/S01861042(14)71265-3

Catoiu, I., Orzan, M., Macovei, O. I., and Iconaru, C., 2014. Modelarea increderii utilizatorilor in retelele de socializare online. Amfiteatru Economic, 16(35), 257-271.

Chigbu, E., Akujuobi, L., and Appah, E., 2012. An Empirical Study on the Causality between Economic Growth and Taxation in Nigeria, Current Research. Journal of Economic Theory, 42, 29-38.

Cleophas, T. J., and Zwinderman, A. H., 2015. Structural Equation Modeling SEM with SPSS Analysis of Moment Structures Amos for Cause Effect Relationships in Pharmaco dynamic Studies II 35 Patients Machine Learning in Medicine - a Complete Overview: Springer. http://dx.doi.org/10.1007/978-3-319-15195-3_49

Cohen, J., 1988. Statistical power analysis for the behavioral sciences (2nd ed.). Hillsdale: Erlbaum.

Cohen, J., 1992. A power primer. Psychological Bulletin, 112, 155-159. http://dx.doi.org/10.1037/00332909.112.1.155

Cooper, G., 1994. The benefit theory of taxation. Australian Tax Forum, 114, 397-509.

Cortina, J. M., 1993. What is coefficient alpha? An examination of theory and applications. The Journal of Applied Psychology, 781, 98-104. http://dx.doi.org/10.1037/0021-9010.78.1.98

Easterly, W., and Rebelo, S., 1993. Fiscal policy and economic growth. Journal of Monetary Economics, 323, 417-458. http://dx.doi.org/10.1016/0304-3932(93)90025-B

European Commission, 2019. The EU's economic governance explained. ECB Economic Bulletin, (2). https://www.ecb.europa.eu/pub/economic-

bulletin/focus/2019/html/ecb.ebbox201902_07 347d73fa31.en.html.

Gale, W. G., and Samwick, A. A., 2014. Effects of Income Tax Changes on Economic Growth. The Brookings Institution by a grant from the Peter G. Peterson Foundation.

Gashi, B., Asllani, G., and Boqolli, L., 2018. The Effect of Tax Structure in Economic Growth International Journal of Economics and Business Administration, VI(2), 56-67. http://dx.doi.org/10.35808/ijeba/157

Gignac, G. E., and Szodorai, E. T., 2016. Effect size guidelines for individual differences researchers Personality and Individual Differences, 102, 74-78. http://dx.doi.org/10.1016/j.paid.2016.06.069

Gius, M. P., and Frese, P., 2002. The Impact of State Personal and Corporate Tax Rates on Firm Location. Applied Economics Letters, 9(1), 47-49. http://dx.doi.org/10.1080/13504850110046859

Goss, E. P., and Phillips, J. M., 1994. State Employment Growth: The Impact of Taxes and Economic Development Agency Spending. Growth and Change, 25(3), 287-300. http://dx.doi.org/10.1111/j.1468-2257.1994.tb00145.x 
Haas, J. S., D'Erman, V. J., Schulz, D. F., and Verdun, A., 2020. Economic and fiscal policy coordination after the crisis: Is the European Semester promoting more or less state intervention? journal of European Integration, 423, 327-344. http://dx.doi.org/10.1080/07036337.2020.1730356

Hair, J. F. J., Hult, G. T. M., Ringle, C. M., and Sarstedt, M., 2014. A Primer on Partial Least Squares Structural Equation Modeling (PLS-SEM): Sage Publications.

Hayat, M. A., Ghulam, H., Batool, M., Naeem, M. Z., Ejaz, A., Spulbar, C., and Birau, R., 2021. Investigating the Causal Linkages among Inflation, Interest Rate, and Economic Growth in Pakistan under the Influence of COVID-19 Pandemic: A Wavelet Transformation Approach. Journal of Risk and Financial Management, 14(6), 277. http://dx.doi.org/10.3390/jrfm14060277

Henseler, J., Ringle, C. M., and Sinkovics, R. R., 2009. The use of partial least squares path modeling in international marketing Advances in International Marketing (Vol. 20, pp. 277-319): Emerald Publishing Limited. http://dx.doi.org/10.1108/S1474-7979(2009)0000020014

Hulland, J., 1999. Use of partial least squares PLS in strategic management research: A review of four

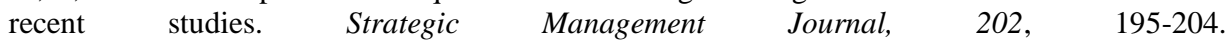
http://dx.doi.org/10.1002/(SICI)1097-0266(199902)20:23.0.CO;2-7

Judd, K., 1985. Redistributive Taxation in a Simple Perfect Foresight Model. Journal of Public Economics, 28(1), 59-83. http://dx.doi.org/10.1016/0047-2727(85)90020-9

Khumbuzile, D., and Hlalefang, K., 2018. The impact of Taxation on Economic Growth in South Africa. MPRA, 86219. https://mpra.ub.uni-muenchen.de/86219.

Kotlan, I., Machova, Z., and Janickova, L., 2011. The impact of the building on long-term economic growth. Vliv zdaneni na dlouhodoby ekonomicky rust. Political economy. Politicka Ekonomie, 59(5), 638-658.

Kwong-Kay Wong, K., 2013. Partial Least Squares Structural Equation Modeling PLS-SEM Techniques Using SmartPLS. Marketing Bulletin, 24(1), 32.

Lapatinas, A., Kyriakou, A., and Garas, A., 2019. Taxation and economic sophistication: Evidence from OECD countries. PLoS One, 14, e0213498. http://dx.doi.org/10.1371/journal.pone.0213498

Lee, Y., and Gordon, R. H., 2005. Tax structure and economic growth. Journal of Public Economics, 895(6), 1027-1043. http://dx.doi.org/10.1016/j.jpubeco.2004.07.002

Macek, R., 2015. The Impact of Taxation on Economic Growth: Case Study of OECD Countries. Review of Economic Perspectives, 14(4), 309-328. http://dx.doi.org/10.1515/revecp-2015-0002

McNemar, Q., 1946. Opinion-attitude methodology. Psychological Bulletin, 43, 289-374. http://dx.doi.org/10.1037/h0060985

Myles, G. D., 2000. Taxation and Economic Growth. Fiscal Studies, 211, 141-168. http://dx.doi.org/10.1111/j.1475-5890.2000.tb00583.x

Nayak, S., Kumar, V. S. G., Mendon, S., Birau, R., Spulbar, C., Srikanth, M., and Doaga, I. D., 2021. The effects of government expenditure on sustainable economic growth in India: Assessment of the circular economy. Industria Textila (Bucuresti), 72(1), 74-80. http://dx.doi.org/10.35530/IT.072.01.1791

Pearl, J., 2000. Causality, Reason, and Inference: Cambridge University Press.

Pribeanu, C., 2012. Un model formativ de masurare a valorii motivationale a unei aplicatii educationale bazate pe realitate îmbogatita. Revista Romana de Interactiune Om-Calculator, 5, 13-18.

Rigdon, E. E., and Marcoulides, G. A., 1998. Structural equation modeling Modern methods for business research (pp. 251-294): Lawrence Erlbaum Associates, Publishers.

Romero, D., and Strauch, R., 2008. Publice Finance on long-term growth in Europe: Evidence from panel data analysis. European Journal of Political Economy, 24, 172-191. http://dx.doi.org/10.1016/j.ejpoleco.2007.06.008

Sarstedt, M., Ringle, C. M., Ramayah, T., and Ting, H., 2018. Convergent Validity Assessment of Formatively Measured Constructs in PLS-SEM: On Using Single-Item versus Multi-Item Measures in Redundancy Analyses. International Journal of Contemporary Hospitality Management, 3011, 3192-3210. 
Seward, T., 2008. The Impact of Taxes on Employment and Economic Growth: Evidence from the Industrialized countries. MPRA, 16574. https://mpra.ub.uni-muenchen.de/16574/.

Shuai, X., and Chmura, C., 2013. The Effect of State Corporate Income Tax Rate Cuts on Job Creation. Business Economics (Cleveland, Ohio), 48(3), 183-193. http://dx.doi.org/10.1057/be.2013.21

Solow, R. M., 1956. A Contribution to the Theory of Economic Growth. The Quarterly Journal of Economics, 70(1), 65-94. http://dx.doi.org/10.2307/1884513

Spulbar, C., Tenea, A. C., Stanciu, C. V., and Birau, R., 2020a. Is there a common path for the integration of European Union banking systems? Ekonomska Istrazivanja, 33(1), 399-419. http://dx.doi.org/10.1080/1331677X.2019.1700386

Spulbar, C., Trivedi, J., and Birau, R., 2020b. Investigating abnormal volatility transmission patterns between emerging and developed stock markets: A case study. Journal of Business Economics and Management, 21(6), 1561-1592. http://dx.doi.org/10.3846/jbem.2020.13507

Stiglitz, J. E., 2010. Taxation in Developing Countries. Six Case Studies and Policy Implications: Columbia University Press. http://dx.doi.org/10.7312/gord14862

Stoilova, D., 2016. Tax structure and economic growth: Evidence from the European Union Sistema fiscal y el crecimiento economico: evidencia de la Union Europea. Contaduria y Administracion, 62, 1041-1057. http://dx.doi.org/10.1016/j.cya.2017.04.006

Swan, T. W., 1956. Economic Growth and Capital Accumulation. Economic Record, 32(63), 334-361.

Tanzi, V., and Zee, H. H., 2000. Tax Policy for Emerging Markets: Developing Countries. National Tax Journal, 53(2), 299-322.

Trivedi, J., Spulbar, C., Birau, R., and Mehdiabadi, A., 2021. Modelling volatility spillovers, crossmarket correlation and co-movements between stock markets in European Union: an empirical case study. Business, Management and Economics Engineering, 19(1), 70-90. http://dx.doi.org/10.3846/bmee.2021.13588

\section{Copyright}

This article is an open access article distributed under the terms and conditions of the Creative Commons Attribution-NonCommercial-NoDerivatives 4.0 International License. 


\section{ANNEX 1}

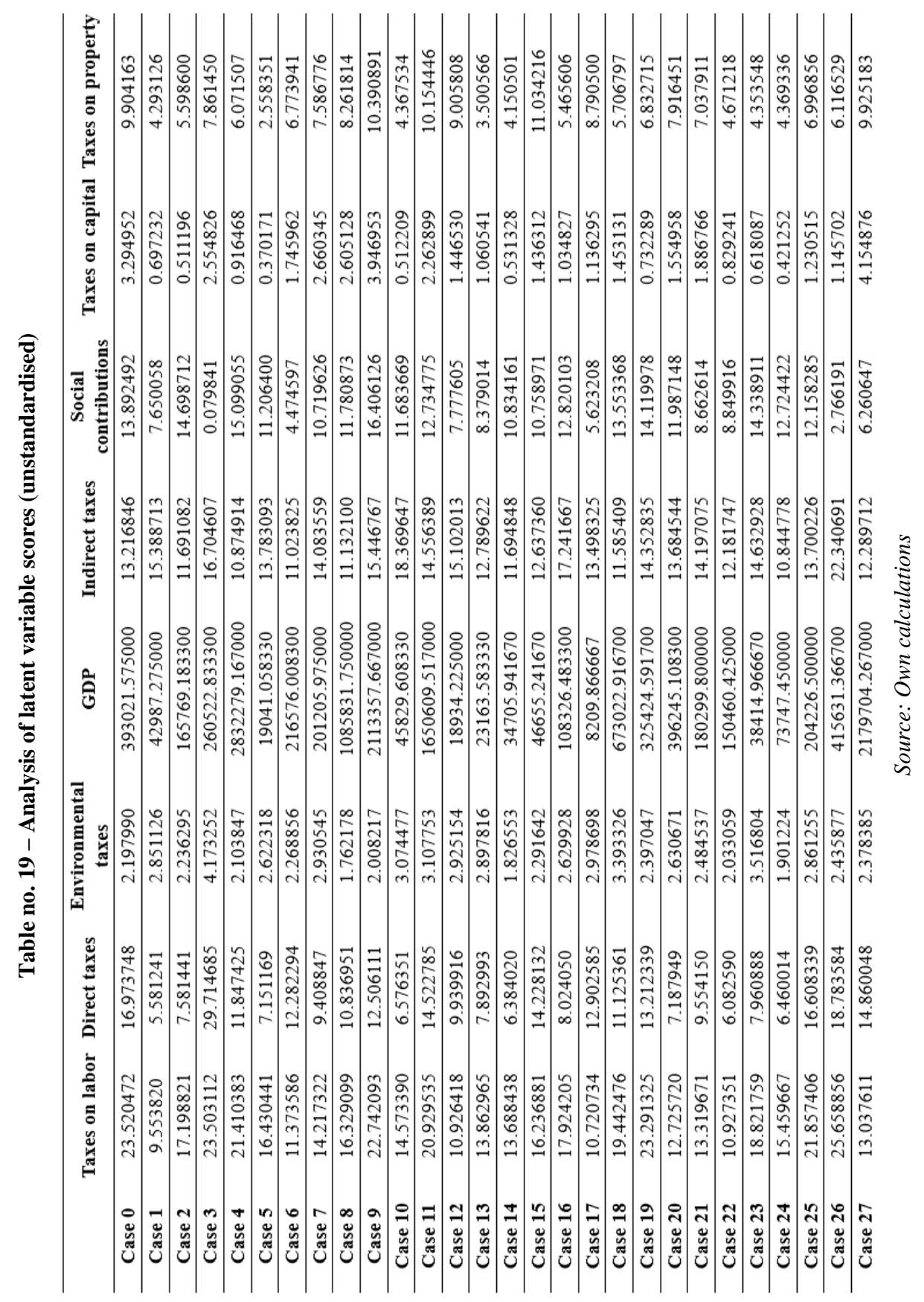

